\title{
TECHNIQUES FOR CONTROLLING THE SURROUNDINGS OF HISTORIC SITES
}

\author{
Russell L. Brenneman*
}

It is not enough merely to preserve historic buildings. To secure the entire value of such an effort, the surroundings of the building must be controlled. Were factories or modern business facades allowed to locate immediately adjacent to a historic structure, the resulting density, noise, or debris might totally destroy the character which made the building worth preserving. The purpose of this article is to present a brief outline of techniques which might be employed to achieve the necessary control of the environment in which the historic building continues to function. The treatment of these techniques is intentionally not exhaustive, and the intricacies of property law doctrine are not detailed. The emphasis, rather, is on listing traditional control devices and stating their adaptability to contemporary preservation efforts. More detailed discussions are available elsewhere. ${ }^{1}$

The dwindling of the rural landscape in the United States which became particularly obvious during the decades of the fifties and sixties prompted concern about preservation of the amenities of open space, particularly in and near large cities. ${ }^{2}$ While the spokesmen for this concern had previously come from a limited group of planners and conservationists, in the last decades a much broader segment of the public added its support to efforts to preserve this resource. This support was translated into legislative and administrative policies which attempted a balance between the desire for open space and traditional notions of the private landowner's prerogatives in the use of his land. Seldom was it found necessary to disturb the existing uses of the land; rather, preservation of open space was achieved by control over the future development of property.

The initial controls took the form of an exercise of the regulatory power of government, specifically the power to zone and to control subdivisions. ${ }^{3}$ Zoning control presents several problems, however, the impact of which is particularly severe for historic preservationists. There is first the risk that the needed control will be so

- Director, Conservation Law Foundation of New England, Boston, Massachusetts. Member of the firm of Copp, Brenneman \& Tighe, New London, Connecticut.

1 See generally S. Siegei, The Law of Open Space 29-32 (I960); A. Dunham, Preservation of Open Space Areas (ig66); R. Brenneman, Private Approsches to the Preservation of Open Land (1967).

2 Notable among much literature on this phenomenon is W. Whyte, SEcuring Open Space roR Urban America: Conservation Easements (Úrban Land Institute, Tech. Bull. No. 36, r959).

${ }^{3}$ See generally Eveleth, An Appraisal of Techniques to Preserve Open Space, 9 VIL.. L. REv. 559 (I964); Cutler, Legal and Illegal Methods for Controlling Community Growth on the Urban Fringe, I96r WIs. L. Rev. 370; Krasnowiecki \& Paul, The Preservation of Open Space in Metropolitan Areas, Iro U. PA. L. Rev. 779 (I96I); Note, Techniques for Preserving Open Spaces, 75 HaRv. L. Rev. I622 (I962); Comment, Preserving Rural Land Resources: The California Westside, I Ecology L.Q. 330 (r97I). 
extensive as to go beyond constitutional prohibitions against taking land without compensation. Moreover, zoning is most acceptable for fairly large, multiple-tract areas, and has not been useful where there is need for controls tailored to relatively small areas. Indeed, where the control amounts to spot-zoning, it will not be legally permissible. ${ }^{4}$ And because zoning must apply to large areas, the extent of control achieved may not be satisfactory for historic preservation in communities which regard land development as the solution to fiscal needs. Finally, exercise of control through the zoning power is necessarily limited to government. Those in the private sector involved in preservation efforts cannot use it even if they are prepared to compensate the landowner for accepting the imposition of controls on his land use.

These limitations prompted a search for other methods for securing control of land development. Attractive alternatives, the development of which paralleled the interest in zoning, involved the acquisition of less-than-fee interests in land and the imposition of controls through covenants and reverter rights. The emphasis of this approach is upon traditional property concepts rather than governmental regulatory powers, and as such has a number of advantages. The nature of the control can be individualized to the parcel upon which open space is sought. The owner can be paid for the right he relinquishes. Unlike the zoning control, estate interest limitations can be utilized by both public and private interests. Moreover, since the control is not subject to the direction of a governmental body, it is less susceptible to policy changes. Finally, operation of the property right control is not dependent upon a government structure for evaluation of compliance and requests for variance. Rather, it enjoys the simplicity of a two party contract, but is subject to judicial scrutiny in the event of a dispute.

Control through less-than-fee interests in land has proved to be both a popular and useful approach, ${ }^{5}$ although its utility in the preservation of the environs of historic places has not been fully explored. The portions of the paper which follow outline the major examples of these types of property control. The task remaining for the preservationist is the design of creative applications of these.

\section{I}

\section{Traditional Devices}

\section{A. Conservation Easements}

The essence of a conservation easement, sometimes called an open space or scenic easement, is that all or some of the development rights associated with a parcel of land are stripped from the fee. ${ }^{6}$ This can be done either by an affirmative grant of those rights or, as is perhaps more often the case, by an expression of the present

\footnotetext{
I A. Ratheropf, Zoning and Planning $\$ 26$ (3d ed. ig62); I E. Yomiey, Zoning Law and Practice $\$ \$ 3.5,8.3$ (3d ed. x965).

'Wisconsin's experience with easements, for example, is detailed in Note, Progress and Problems in Wisconsin's Scenic Conservation Program, 1965 WIs. L. REv. 352.

'See generally W. Whyte, stupra note 2.
} 
title holder that the land shall not be developed thereafter. It is intended that the easement shall control the land forever and that the development limitation shall be enforceable either by the original holder of the easement or any person to whom the holder may have transferred his rights. The holder of the easement need not have any interest in the land burdened by the easement.

In summary, several characteristics can be ascribed to this type of easement in its most desirable form. The landowner retains the fee. The easement benefits no land and, hence, in terms of traditional property concepts is an easement in gross. The easement protects land against development and is binding upon future owners of the burdened land. The easement is transferable.

If these characteristics are present, the conservation easement is a very flexible device and quite useful in preservation work. The preservation planner must be aware, however, that local statutes or judicial interpretations may limit particular features of this mechanism. Several recurring questions under local law can be identified. In some jurisdictions, there may be a question whether a grant of this sort is an easement at all. It might be viewed as a covenant, a result which could have great significance because of the difference in the legal effect of these two interests. Some of these differences are mentioned below. Even if it is assumed that an easement of some type exists, it is necessary to determine whether a conservation easement will be enforceable in those jurisdictions which seemingly restrict easements to special categories. ${ }^{7}$

A more critical problem faced by the planner is whether his jurisdiction permits the assignment of easements in gross. ${ }^{8}$ In the absence of a statute, the prevailing view in this country is that an easement in gross is destroyed if the original holder attempts its transfer. ${ }^{9}$ Non-transferability may not be a problem in situations in which the easement is held by a government agency, private foundation, or other body likely to have a perpetual existence. However, transfers from one agency or foundation to another are not uncommon and may be occasioned by reorganization, dissolution, or a loss of financial support. Because the control intended by the conservation easement can be so easily destroyed, selection of the holder of the easement requires particular attention.

In those jurisdictions which prohibit transfer, continuation of the desired control can be achieved if the easement is made appurtenant to land owned by the easement holder. In these circumstances, the easement is no longer one in gross, and transfer of the easement will be permissible if it accompanies a transfer of the land to which

\footnotetext{
'For a stuffy English view, read the opinion of the Lord Chancellor in Keppel v. Bailey, 39 Eng. Rep. 1042, I049 (Ch. I834). A more modern view is expressed in Restatement of Property \$450, comment $l$ (r944). In the United States mere novelty will not invalidate a conservation eascment. 3 R. Poweld, Law of Reai Property ff 429, at 526.75 ( $\mathrm{xg66}$ ).

${ }^{8}$ See generally 2 American Law of Property $\$ 8.9$ (A. Casner ed. i952).

'C. Clark, Real Covenants and Other Interests Which "Run with Land" 67-69 (2d ed. i947) discussed the rule and the reasons advanced for it. Commercial easements are assignable. R. PowzLr, supra note 7, $\$ 419$, at 526.9. See generally, Simes, The Assignability of Easements in Gross in American Law, 22 Micr. L. REv. 521 (1924).
} 
it is related. This solution is most feasible either where the party interested in preservation, such as the government, owns the land surrounding the historic site or where private owners of surrounding land have a special interest in the maintenance of an historic property, as in the case of a neighborhood with historic significance.

\section{B. Covenants and Equitable Restriction}

In searching for control mechanisms, a planner might suppose that the desired protection could be secured by a promise not to develop the land made at the time of a conveyance. For example, a foundation or government agency undertaking historic preservation may seek to include such a promise in the title documents when it purchases or accepts a contribution of land surrounding an historic property. The careful planner would provide that the promise would be binding not only on the immediate transferee agency or foundation, but also upon those to whom the property is subsequently transferred. And if the original owner were transferring the property as a gift, he would demand inclusion of language allowing him to transfer the right to enforce the promise.

On its face this arrangement appears to provide a sensible and relatively simple means for restricting the development of the transferred land. However, the planner must be mindful of the complexities of the law relating to restrictive covenants. ${ }^{10}$

If it is assumed that the transferor has no continuing interest in other adjacent land, the most obvious difficulty with this arrangement is that the promise creates a covenant intended to run with the transferred land but which does not benefit land owned by the promisee. The covenant against development would be enforceable between the original parties, but transfers of the burden or benefit are likely. While the original transferor may seek to assign his right of enforcement, either during his life or, as is more likely, at his death, such a transfer would not be effective. As is true of an easement in gross, the benefit of the covenant is not transferable in most jurisdictions and will die with the original transferor.

Equally significant is the rule that the obligation not to develop the land is not binding on subsequent transferees of the land. In most jurisdictions, the burden of a covenant the benefit of which is held in gross will not run with the land. ${ }^{11}$ Consequently, should the government agency or foundation effectuate a transfer, the restriction against development would not thereafter be enforceable.

The lessons of this analysis should be clear. Because of the certainty of a transfer, neither an individual nor an entity with characteristics of an individual would be an appropriate recipient of land transferred with a covenant the benefit of which did rest on another parcel of land. Moreover, the possibility of a further transfer upon dissolution or reorganization limits the attractiveness of a foundation or agency

\footnotetext{
${ }^{10}$ An excellent short summary of the common law of covenants and equitable restrictions appears in $A$. Dunham, stpra note $x$, at 50-64.

${ }^{11}$ See generally C. Clark, supra note 9, at 92-I43.
} 
recipient. As was true in the case of easements in gross, they are preferably avoided by an arrangement which insures that the benefit is related to another tract of land.

\section{Conditions and Limitations}

Control over land may also result from the existence of a power to terminate an interest in land upon breach of a condition. The distinguishing characteristic of these control methods is that upon the happening of some event title to the fee is transferred, either automatically or through the intervention of the holder of the power of termination, to the original transferor or to a third party. It is, of course the threat of termination which insures that the transferee will comply with the conditions of the transfer.

These devices can be profitably used by both the private donor and the preservation agency. The grant of the private donor may provide, for example, that the grant will endure only as long as the property contributed is used as an historic site, is properly maintained, and is made available to the public. Similar conditions might accompany a transfer made by a foundation or agency, as in the situation where the organization has purchased and restored historic properties and seeks to transfer them to private owners so that they may be put to residential or commercial uses.

In using possibilities of reverter, rights of re-entry, and executory interests, the planner will find that each of these has distinctive and not necessarily predictable characteristics. In the absence of a statute, for example, a right of re-entry is typically not alienable. The possibility of reverter and executory interest, on the other hand, are generally transferable. The trend, however, is toward statutes which eliminate these distinctions so as to enable the transfer of these interests either by inter vivos or testamentary conveyance. ${ }^{12}$

The planner should also attempt to assess the attitudes of the courts and legislature of his jurisdiction toward these devices. Courts have generally preferred constructions which will avoid forfeitures. ${ }^{13}$ Consequently, the conditions intended to terminate the grant should be stated with precision. Also of importance are the state statutes governing the duration of limitations upon estates in land. Under some enactments, the limitation attached to a grant will not be effective if the condition does not occur within a specified number of years. Under others, title will be deemed absolute if an action to enforce a restriction has not occurred within a specified time.

\section{II}

\section{Statutory Devices}

The discussion above should suggest that while conservation easements and covenants have a significant potential utility for preservation work, this potential

\footnotetext{
${ }^{12}$ Many states have such statutes. See, e.g., Mrch. Srat. ANN. \$26.rI (1957).

${ }^{18}$ The usual attitude is well expressed in Ryan v. Porter, 6r Tex. I06, I09 (1884).
} 
cannot be realized in some jurisdictions either because the applicable common law is not clear or because it imposes significant limitations on the flexibility of the devices. Either condition will inhibit experimentation with these interests in preservation transfers. The legislatures in some jurisdictions have accepted the utility of these approaches and have undertaken the statutory changes necessary to encourage their use.

Statutes reflecting these changes were enacted in Massachusetts in $1969^{14}$ and Connecticut in $1977^{15}$ Both states have abandoned the term conservation easement in favor of more descriptive terms. In both states a distinction is made between a conservation restriction, which encompasses limitations so as to preserve natural or scenic conditions, and a preservation restriction, which is designed to control the environs of historic sites. The Massachusetts statute includes the more detailed definition of a preservation restriction. Such a restriction is

a right, whether or not stated in the form of a restriction, easement, covenant or condition, in any deed, will or other instrument executed by or on behalf of the owner of the land or in any order of taking, appropriate to the preservation of a structure or site historically significant for its architecture, archeology or associations, to forbid or limit any or all (a) alterations in exterior or interior features of the structure, (b) changes in appearance or condition of the site, (c) uses not historically appropriate, or (d) other acts or uses detrimental to appropriate preservation of the structure or site. ${ }^{16}$

In each statute there is an attempt to remove common law limitations on conservation easements. Both provide that the statutory restrictions will not be unenforceable because of a lack of privity of estate, because the benefit of the restrictions is not tied to a particular parcel of land or because the benefit has been assigned. ${ }^{17}$ There are, however, significant limitations on the types of entities which can hold such a restriction. The holder must be a governmental body or a charitable corporation or trust established for the purposes of undertaking historic preservation work. Both statutes authorize the use of injunctions to enforce the restrictions. ${ }^{18}$

The Massachusetts statute differs markedly from the Connecticut version by requiring official approval as a prerequisite to the enforceability of a restriction. ${ }^{19}$ All preservation restrictions must be approved by the state historical commission. In addition, preservation restrictions held by a charitable foundation or trust must be approved by both the executive and legislative branches, usually the mayor and city council, of the municipality in which the affected property is located.

While the Massachusetts statutes contemplates that a restriction may be terminated, the Connecticut enactment is silent on this point. The Massachusetts provision

\footnotetext{
${ }^{14}$ Mass. ANn. Laws ch. $184, \$ 26-33$ (Supp. I970).

${ }^{28}$ Conn. Pub. Act 174 (197r).

${ }^{16}$ Mass. ANN. Laws ch. 184 , § 31 (Supp. 1970).

${ }^{17}$ Id. $\S 32$; Conn. Pub. Act r73, $\$ 2$ (I97I).

${ }^{28}$ Mass. Anv. LAws ch. $184, \S 32$ (Supp. I970); Conn. Pub. Act 173, 33 (I971).

${ }^{10}$ Mass. Ans. Laws ch. $184, \$ 32$ (Supp. 1970).
} 
imposes procedures which are apparently intended to insure that some public recognition will accompany the termination so that interested parties may raise objections. A public hearing must be held on the proposed release of a restriction, and the approval of specified officers must be secured. ${ }^{20}$

To assist private and governmental development efforts, the Massachusetts statute provides that a municipality may file a public restriction tract index for the purpose of providing a composite of the tracts subject to outstanding restrictions. ${ }^{21}$ The index includes information concerning the identity of the holder of the restriction and the place of its recordation.

\section{ConcLusion}

The restrictions on land use which are emerging in the context of general conservation law may be useful for controlling the surroundings of historic sites, although this type of application has not been fully developed. The devices are sufficiently flexible in their most useful forms to admit of diverse applications. The desirability of a particular method will depend upon the state of the law in the jurisdiction in which the planner works. Because of the continuing influence of common law property concepts, the planner should be prepared to accept results which are controlled more by the structure than the substance of a particular transaction. Statutory developments in a few states hopefully will eliminate the planners' hesitancy to use these devices. In those states with property laws still restrained by formalistic limitations, an appropriate activity of preservation groups is the drafting and submission of legislation which removes the legal impediments to less-thanfee land controls.

\footnotetext{
${ }^{20} I d$.

${ }^{21}$ Id. $\$ 33$.
} 